\title{
International Union of Basic and Clinical Pharmacology. LXXIV. Apelin Receptor Nomenclature, Distribution, Pharmacology, and Function
}

\author{
Sarah L. Pitkin, Janet. J. Maguire, Tom I. Bonner, and Anthony P. Davenport \\ Clinical Pharmacology Unit, University of Cambridge, Cambridge, United Kingdom (S.L.P., J.J.M., A.P.D.); and Section on Functional \\ Neuroscience, National Institute of Mental Health, Bethesda, Maryland (T.I.B.)
}

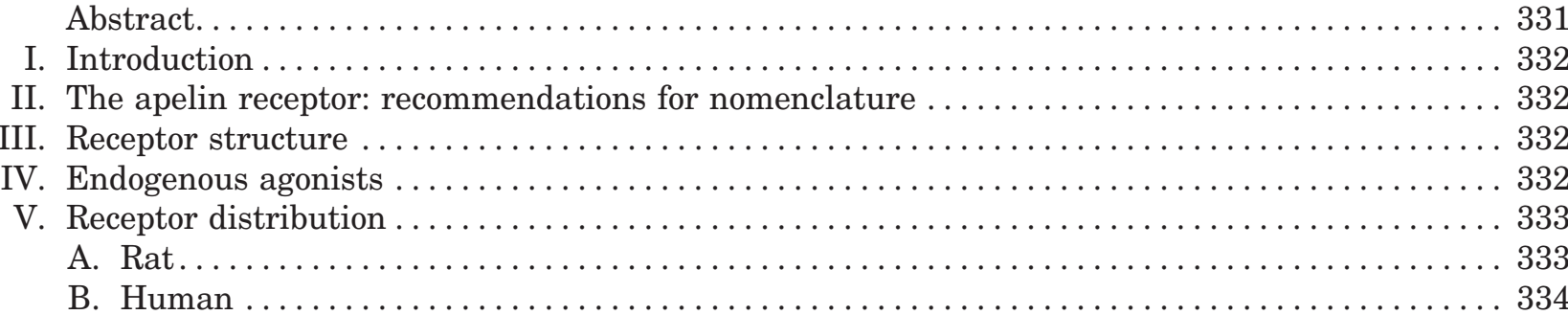

VI. Apelin peptide distribution. . . . . . . . . . . . . . . . . . . . . . . . . . . . . . . . . . . . . . 334

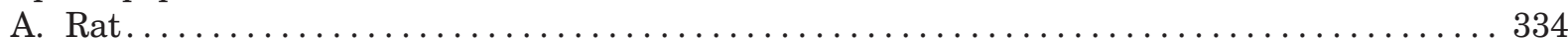

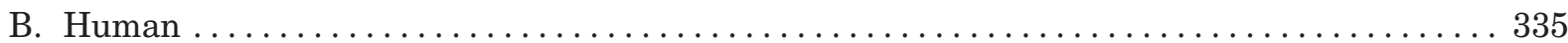

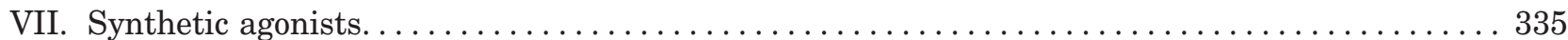

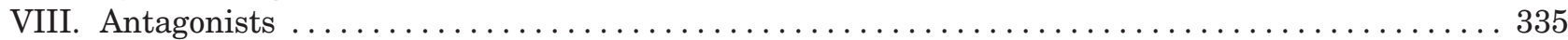

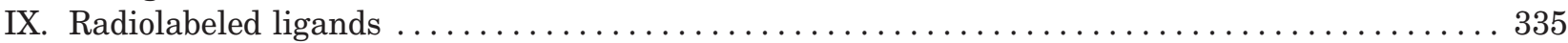

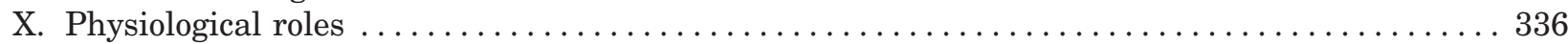

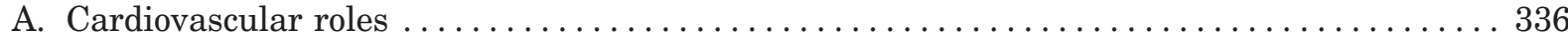

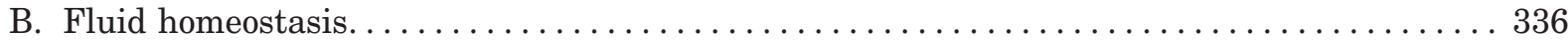

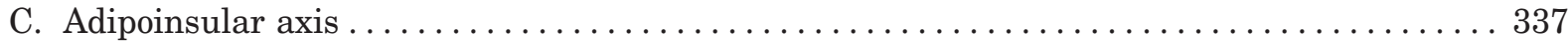

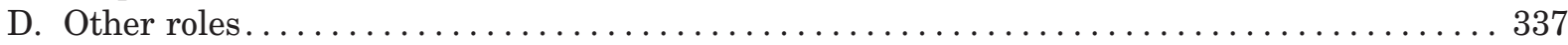

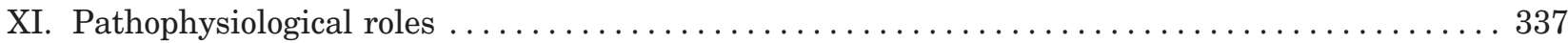

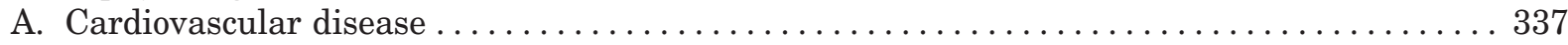

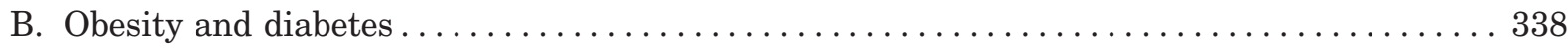

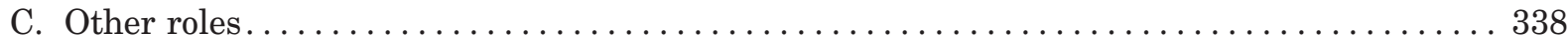

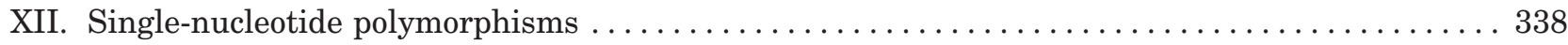

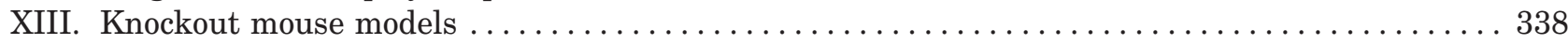

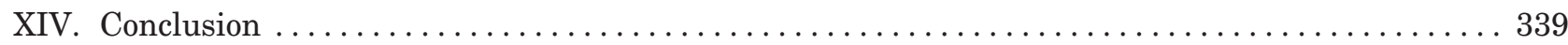

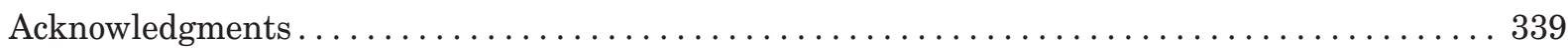

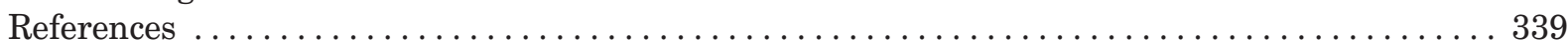

Abstract-CA gene encoding a novel class a Gprotein-coupled receptor was discovered in 1993 by homology cloning and was called APJ. It was designated an "orphan" receptor until 1998, when its endogenous ligand was identified and named apelin (for APJ endoge-

Address correspondence to: Dr. Anthony Davenport, NC-IUPHAR Emerging Pharmacology Group, Clinical Pharmacology Unit, University of Cambridge, Addenbrooke's Hospital, Cambridge, CB2 0QQ, UK. E-mail: apd10@medschl.cam.ac.uk.

This article is available online at http://pharmrev.aspetjournals.org. doi:10.1124/pr.110.002949. nous ligand). Since this pairing, both apelin and its receptor have been found to have a widespread distribution in both the central nervous system and the periphery. A number of physiological and pathophysiological roles for the receptor have emerged, including regulation of cardiovascular function, fluid homeostasis, and the adipoinsular axis. This review outlines the official International Union of Pharmacology Committee on Receptor Nomenclature and Drug Classification nomenclature, designating the receptor protein as the apelin receptor, together with current knowledge of its pharmacology, distribution, and functions. 


\section{Introduction}

Since the discovery of the gene encoding the apelin receptor, originally called APJ, and pairing of the protein with its cognate ligands, the apelin peptides, a number of physiological and pathophysiological roles for the receptor have emerged. These include cardiovascular regulation, fluid homeostasis, modulation of the adipoinsular axis, and HIV coreceptor function in vitro. Here we summarize the discovery, deorphanization, and recommended nomenclature with subsequent characterization of the physiological and pathophysiological roles of the apelin receptor. The primary aim of this review is to outline the recommended nomenclature for this receptor. For comprehensive overviews of the apelin field, see Kleinz and Davenport (2005), Masri et al. (2005), Carpéné et al. (2007), Davenport et al. (2007), and Ladeiras-Lopes et al. (2008). Details of the pairing of APJ with apelin are outlined in Hinuma et al. (1999). For more information on the roles of apelin and its receptor in cardiovascular function, see Lee et al. (2006), Sorli et al. (2006), Chandrasekaran et al. (2008), Japp and Newby (2008), Quazi et al. (2009), and Kalea and Batlle (2010). The involvement of apelin in fluid homeostasis is described by Brown et al. (2008), Bundzikova et al. (2008) and Llorens-Cortes and Moos (2008). CastanLaurell et al. (2005), Bełtowski (2006), Lee et al. (2006), and Rayalam et al. (2008) specifically review the contribution of this system in the adipoinsular axis.

\section{The Apelin Receptor: Recommendations for Nomenclature}

In 1993, a gene encoding a novel class A G-proteincoupled receptor $\left(\mathrm{GPCR}^{1}\right)$ was discovered by homology cloning. It was located on chromosome 11 band q12 and showed greatest sequence homology with the angioten$\sin \mathrm{AT}_{1}$ receptor (54\% in the transmembrane regions) but did not bind angiotensin II. It was therefore designated an "orphan" GPCR, having no known ligand, and was named APJ by O'Dowd et al., (1993). The approved Human Genome Organization (HUGO) gene symbol for $A P J$ is now APLNR. The gene has a number of other aliases, including AGTRL1, APJ, APJR, and FLJ90771. The endogenous ligand for this receptor was later identified as apelin, which led the International Union of Pharmacology (IUPHAR) to recommend "apelin receptor" as the nomenclature for the receptor protein (Davenport and Kleinz, 2008) (Table 1). This follows the convention of naming the receptor protein after its endogenous ligand.

\footnotetext{
${ }^{1}$ Abbreviations: GPCR, G-protein-coupled receptor; IUPHAR, International Union of Pharmacology; AT, angiotensin; CHO, Chinese hamster ovary; ACE, angiotensin-converting enzyme; CNS, central nervous system; SON, supraoptic nucleus; PVN, paraventricular nucleus; SNP, single-nucleotide polymorphism; $\mathrm{p} K_{\mathrm{D}}$, the negative log 10 of the equilibrium dissociation constant of a ligand determined directly in a binding assay using a labeled form of the ligand.
}

\section{Receptor Structure}

The human apelin receptor comprises 380 amino acid residues and has the typical 7-transmembrane domain structure of a class A GPCR. It contains consensus sites for phosphorylation by cAMP-dependent protein kinase, palmitoylation, and glycosylation (O'Dowd et al., 1993). The apelin receptor has been identified in a number of other species, including mouse, rat, cow, rhesus macaque, Xenopus laevis, and Danio rerio. The mouse apelin receptor has 377 amino acids and 91\% sequence homology with the human receptor, whereas the rat apelin receptor has 377 amino acids and $89 \%$ sequence homology with the human receptor (Fig. 1).

To date, there is no evidence for multiple receptor subtypes in mammals. During the initial receptor identification, a polymerase chain reaction strategy using oligonucleotides based on the apelin receptor yielded no closely related genes (O'Dowd et al., 1993). In addition, saturation binding experiments in human tissues gave Hill coefficients close to unity, indicating that the radioligand bound to a single receptor population (Katugampola et al., 2001), although this does not exclude the possibility of two receptor subtypes with the same affinity.

Activation of apelin receptors expressed in cell lines inhibited forskolin-stimulated cAMP production, suggesting that the receptor is coupled to inhibitory G-proteins $\left(\mathrm{G}_{\mathrm{i}}\right)$ (Habata et al., 1999), which is supported by the finding that apelin actions are pertussis toxin-sensitive (Hosoya et al., 2000; Masri et al., 2002). A number of interactions between the apelin and angiotensin systems have been reported, including recent evidence that the apelin receptor forms heterodimers with the angiotensin $\mathrm{AT}_{1}$ receptor (Chun et al., 2008).

\section{Endogenous Agonists}

In 1998, the endogenous ligand for APJ was identified as a 36-amino acid peptide named apelin (for APJ endogenous ligand), isolated from bovine stomach extracts. This peptide induced extracellular acidification in $\mathrm{CHO}$ cells expressing apelin receptors (Tatemoto et al., 1998). cDNA encoding a 77-amino acid prepropeptide (preproapelin) was identified in human and bovine tissue (Tatemoto et al., 1998), showing considerable sequence similarity across all species examined, with the last 23 residues of the $\mathrm{C}$ terminus being identical in mammals (Fig. 2).

Native preproapelin exists as a dimer, stabilized by disulfide bridges, in mouse heart (Lee et al., 2005). Preproapelin contains a number of paired basic amino acids residues (Arg-Arg and Arg-Lys) that are possible cleavage sites for endopeptidases (Habata et al., 1999). Cleavage at these sites would produce a predicted family of C-terminal fragments, including apelin-36, apelin-17, apelin-13, and the post-translationally modified ( $\mathrm{Pyr}^{1}$ )apelin-13 (Fig. 3), which are all agonists at the apelin receptor (Table 2). The lack of cysteine residues in these C-terminal fragments suggests that the mature peptides are monomeric. 


\begin{tabular}{|c|c|}
\hline \multirow{4}{*}{$\begin{array}{l}\text { RAT } \\
\text { MOUSE } \\
\text { HUMAN }\end{array}$} & MED DG - -YNYYGADNQSECDYADWT PSGAL I A I I I LVF L \\
\hline & MEDDG--YNYYGADNQSECDYADWKPSGAL I PA I YMLVFL \\
\hline & MEEGGDF DNYYGADNQSECEYTDWKSSGAL I PA I YMLVF L \\
\hline & 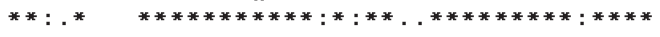 \\
\hline RAT & RRSAD IF I ASLAVADL TFVVTL PL WATYTYREF DWPFGTF \\
\hline MOUSE & RRSADIF I ASLAVADLTFVVTLPLWATYTYREF DWPFGTF \\
\hline \multirow[t]{2}{*}{ HUMAN } & RRSADIFIASLAVADLTFVVTLPLWATYTYRDYDWPFGTF \\
\hline & 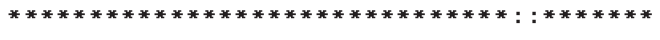 \\
\hline RAT & TGLSFDRYLAIVRPVANARLRLRVSGAVATAVLWVLAALL \\
\hline MOUSE & TGLSFDRYLAIVRPVANARLRLRVSGAVATAVLWVLAALL \\
\hline \multirow[t]{2}{*}{ HUMAN } & TGLSFDRYLAIVRPVANARLRL RVSGAVATAVLWVLAALL \\
\hline & $\begin{array}{l}* \\
*\end{array}$ \\
\hline RAT & CYMDYSMVATSNSEWAWEVGLGVSSTAVGFVVPF I I MLTC \\
\hline MOUSE & CYMDYSMVATSNSEWAWEVGLGVSSTAVGFVVPFT IMLTC \\
\hline \multirow[t]{2}{*}{ HUMAN } & CYMDYSMVATVSSEWAWEVGLGVSSTTVGFVVPFTIMLTC \\
\hline & \%******m, \\
\hline RAT & RKRRRL LS I IVVLVVTF ALCWMPYHL VKTL YMLGNL LHWP \\
\hline MOUSE & RKRRRL LS I IVVLVVTF AL CWMPYHLVKTL YMLGSL LHWP \\
\hline \multirow[t]{2}{*}{ HUMAN } & RKRRRLLS I IVVLVVTF ALCWMPYHLVKTL YMLGSLLHWP \\
\hline & 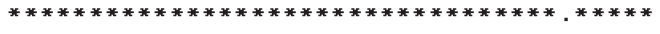 \\
\hline RAT & NSCLNPFLYAFFDPRFRRACTSMLCCDQSGCKGSPHSSSA \\
\hline MOUSE & NSCLNPFLYAFF DPRF RQACTSMLCCDQSGCKGTPHSSSA \\
\hline \multirow{2}{*}{ HUMAN } & NSCLNPFLYAFFDPRFRQACTSMLCCGQSRCAGTSHSSSG \\
\hline & 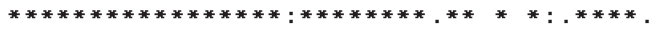 \\
\hline RAT & GGEPMHEKSIPYSQETLVD - 377 \\
\hline MOUSE & GGEQMHEKSIPYSQETLVD - 377 \\
\hline \multirow[t]{2}{*}{ HUMAN } & GGEQMHEKS I PYSQETLVVD 380 \\
\hline & ***************** \\
\hline
\end{tabular}

LGTTGNGLVLWTVFWSSREK 58 LGTTGNGL VLWTVFRTSREK 58 LGTTGNGLVLWTVFRSSREK 60 *************:;***

SCKLSSYLIFVNMYASVFCL 118 SCKLSSYL I FVNMYASVFCL 118 FCKLSSYL I FVNMYASVFCL 120

$* * * * * * * * * * * * * * *$

AVPVMVF RSTDI PENSTKTQ 178 AVPVMVFRSTDASENGTKIQ 178 AMPVMVLRTTGDLENTTKVQ 180 $*: * * *: *: * \quad * * * * *$

YFFIAOTIAGHF RKERIEGL 238 YFFIAQTIAGHF RKERIEGL 238 YFFIAQTIAGHF RKERIEGL 240

$* * * * * * * * * * * * * * * * * * *$

CDFDSFLMNVF PYCTCISYV 298 CDFDIFLMNVF PYCTCISYV 298 CDFDLFLMNIFPYCTCISYV 300

********:*********

EKSASYSSGHSOGPGPNMCK 358 EKSASYSSGHSQGPGPNMGK 358 EKSASYSSGHSQGPGPNMGK 360

$* * * * * * * * * * * * * * * * * *$

FIG. 1. Alignment of human, rat, and mouse apelin receptors. *, identical amino acids, :, conserved amino acid substitution; ., semiconserved amino acid substitution.

The degradative pathway for apelin peptides is unknown, but the recently identified angiotensin-converting enzyme 2 (ACE2) cleaves the C-terminal phenylalanine from apelin-13 and apelin-36 (Vickers et al., 2002). However, this cleavage is unlikely to inactivate the peptide, because an in vitro structure activity study showed that a fragment lacking this residue retained binding and functional activity at the rat apelin receptor expressed in $\mathrm{CHO}$ cells (El Messari et al., 2004). However, this fragment did not induce apelin receptor internalization in vitro and lost hypotensive activity in the rat in vivo, suggesting that cleavage by ACE2 may produce apelin fragments that induce a conformational state of the apelin receptor different from that induced by the full-length peptides (El Messari et al., 2004). It has recently been reported that $\left(\mathrm{Pyr}^{1}\right)$ apelin-13, lacking the C-terminal phenylalanine, has comparable affinity and agonist activity at the native apelin receptor in human tissues in vitro (Pitkin et al., 2009), suggesting that cleavage of apelin by ACE2 is not an inactivating step in man.

The existence of multiple predicted apelin isoforms raises the question of which isoform is most important in

$$
\begin{aligned}
& \text { HUMAN LVQPRGSRNGPGPWQGGRRKFRRQRPRLSHKGPMPF } \\
& \text { RAT LVKPRTSRTGPGAWQGGRRKFRRQRPRLSHKGPMPF } \\
& \text { MOUSE LVKPRTSRTGPGAWQGGRRKFRRQRPRLSHKGPMPF } \\
& \text { BOVINE } 1 \text { LVQPRGPRSGPGPWQGGRRKFRQRPRLSHKGPMPF } \\
& \text { ZEBRAFISH PLRQNPARAGRSQRPAGWRR-RRPRPRLSHKGPMPE } \\
& \text { Xenopus laevis LVNPKMVRNSAPQRQANRRKLIRQRPRLSHKGPMPF }
\end{aligned}
$$

FIG. 2. Sequence alignment of mammalian, fish and amphibian apelin-36 amino acid sequences. *, identical amino acids; :, conserved amino acid substitution; ., semiconserved amino acid substitution. Residues that differ from the human sequence are highlighted in red. vivo. All of these predicted isoforms have been shown to be present in vivo, but the predominant apelin isoform in human cardiac tissue is $\left(\mathrm{Pyr}^{1}\right)$ apelin-13 (Maguire et al., 2009), which is not unexpected because the pyroglutamate moiety protects the $\mathrm{N}$ terminus of peptides from exopeptidase degradation (Van Coillie et al., 1998). The predominant isoforms in plasma are $\left(\mathrm{Pyr}^{1}\right)$ apelin-13, apelin-13 and apelin-17 (De Mota et al., 2004; Miettinen et al., 2007; Azizi et al., 2008), whereas apelin-36 is the major isoform present in colostrom (Hosoya et al., 2000). Rat brain was found to contain both $\left(\mathrm{Pyr}^{1}\right)$ apelin-13 and apelin-17 (De Mota et al., 2004).

The relative potency of the apelin peptides varies between experimental systems, $\left(\mathrm{Pyr}^{1}\right)$ apelin-13 and apelin-13 being the most potent activators of apelin receptors expressed in cell lines (Tatemoto et al., 1998; Habata et al., 1999; Kawamata et al., 2001; Medhurst et al., 2003), whereas apelin-36 is the most potent inhibitor of HIV infection of cells in vitro (Zou et al., 2000). However, $\left(\mathrm{Pyr}^{1}\right)$ apelin-13, apelin-13, and apelin-36 are equipotent mediators of vascular tone and cardiac contractility in human tissues in vitro, with $\mathrm{pD}_{2}$ (negative $\log _{10}$ of the molar concentration required to produce halfmaximal response) values in the range of 8.8 to 10.4 (Maguire et al., 2009).

\section{Receptor Distribution}

A. Rat

Within the rat central nervous system (CNS), mRNA encoding the apelin receptor is found in a number of 
a
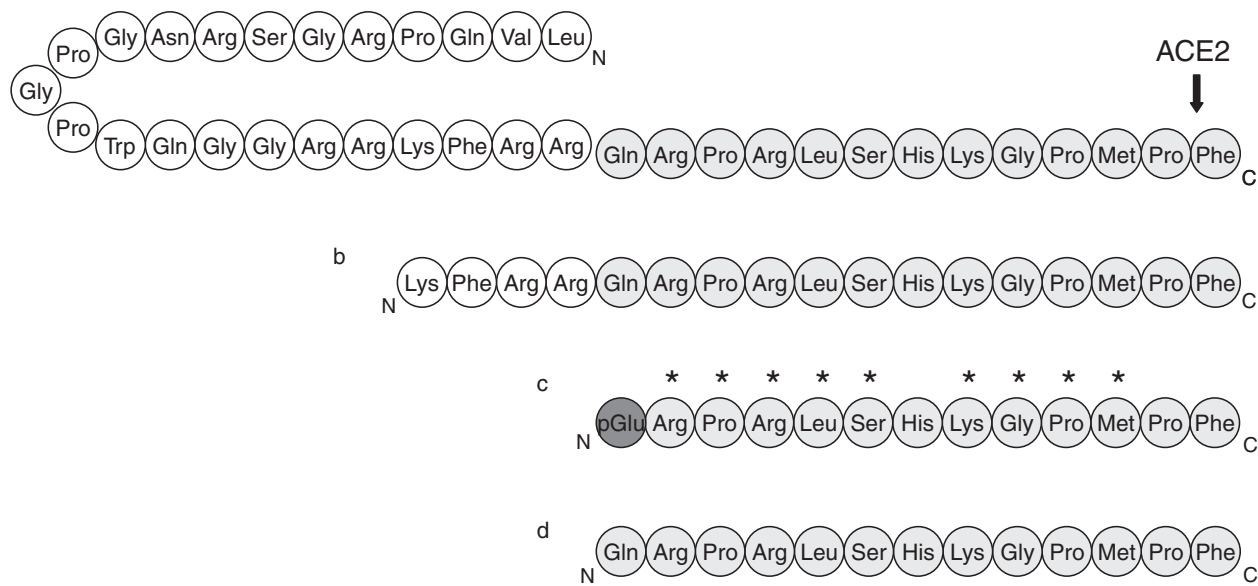

FIG. 3. Amino acid sequence of the endogenous apelin receptor agonists apelin-36 (a), apelin-17 (b), (Pyr ${ }^{1}$ )apelin-13 (c), and apelin-13 (d). Shaded residues are those identical in all peptides. The post-translational modification of the N-terminal glutamate of apelin-13 to pyroglutamate is shown in dark gray. ACE2 cleaves apelin-36 and apelin-13 at the position shown (Vickers et al., 2002). *, residues found to be important for binding and activation of the apelin receptor by apelin-13 (Fan et al., 2003; Medhurst et al., 2003; El Messari et al., 2004).

areas, including the supraoptic (SON) and paraventricular (PVN) nuclei of the hypothalamus, the pineal gland, and the pituitary (De Mota et al., 2000; Lee et al., 2000; O'Carroll et al., 2000). Apelin receptor protein also has a widespread distribution within the rat brain, including the cerebral cortex, basal ganglia, hypothalamus, thalamus, midbrain, and reticular formation (Medhurst et al., 2003). It is noteworthy that apelin receptor mRNA and protein colocalize with vasopressin in a subset of magnocellular neurons within the SON and PVN of the rat hypothalamus (Reaux et al., 2001; O'Carroll and Lolait, 2003; De Mota et al., 2004), suggesting a role for the receptor in water balance.

Apelin receptor transcripts are found in most peripheral rat tissues, the highest levels being found in the lung, heart, and kidney (Hosoya et al., 2000; O'Carroll et al., 2000; Medhurst et al., 2003). Receptor protein is present in rat lung and heart and at lower levels in the kidney cortex (Katugampola et al., 2001).

\section{B. Human}

mRNA encoding the apelin receptor is widely distributed within the human CNS but is highest in the spinal cord, corpus callosum, and medulla (Matsumoto et al., 1996; Edinger et al., 1998; Medhurst et al., 2003;). The distribution of receptor protein within the human brain has not yet been determined.

As in rats, apelin receptor mRNA is found in most human peripheral tissues. However, the highest levels

TABLE 1

IUPHAR recommendations on receptor nomenclature

\begin{tabular}{ll} 
Family name & Apelin receptor \\
Ligand & Apelin \\
Official IUPHAR receptor name & Apelin receptor \\
Human gene name & APLNR \\
Rat gene name & aplnr \\
Mouse gene name & aplnr \\
\hline
\end{tabular}

are found in human spleen and placenta, whereas it is highest in lung in the rat. Receptor is also present in human heart, liver, lung, kidney, and stomach (Edinger et al., 1998; Medhurst et al., 2003). The widespread distribution of apelin receptor transcripts in the periphery was consistent with a vascular localization. Autoradiography revealed apelin binding sites within a range of human large-diameter blood vessels (Katugampola et al., 2001), which was confirmed by immunohistochemistry showing localization of apelin receptor to vascular endothelial and smooth muscle cells (Kleinz et al., 2005). The presence of the apelin receptor on both the vascular endothelium and smooth muscle suggested a role in endothelium-dependent and -independent modulation of vascular tone. Apelin receptors are also present on human cardiomyocytes (Kleinz et al., 2005), raising the possibility of effects on cardiac contractility.

\section{Apelin Peptide Distribution}

\section{A. Rat}

Like its receptor, apelin peptide has a widespread distribution throughout the CNS and periphery, and there is a large amount of overlap in the expression profiles of the receptor and peptide. In the rat, mRNA encoding apelin is found within a number of CNS regions, including the nucleus accumbens, spinal cord, cortex, striatum, midbrain, hippocampus, cerebellum, and pituitary (Lee et al., 2000; Medhurst et al., 2003). Apelin peptide is expressed at highest levels in the rat pineal gland, pituitary, arcuate nucleus, and SON and PVN of the hypothalamus (Reaux et al., 2002; De Mota et al., 2004). Within the SON and PVN, the majority of apelin-positive neurons also express vasopressin (De Mota et al., 2004; Reaux-Le Goazigo et al., 2004).

In the rat periphery, apelin mRNA is highest in the lung, with high levels also found in the mammary gland and heart (Habata et al., 1999; O'Carroll et al., 2000; 
TABLE 2

Actions and affinities of endogenous apelin receptor agonists

\begin{tabular}{lccl}
\hline \multicolumn{1}{c}{ Ligand } & Action & Affinity $\left(\mathrm{pIC}_{50}\right)$ & \multicolumn{1}{c}{ References } \\
\hline Apelin-36 & Full agonist & $8.6-8.3$ & Hosoya et al., 2000; Kawamata et al., 2001; Fan et al., 2003; Medhurst et al., 2003 \\
Apelin-17 & Full agonist & $9.0-7.9$ & Medhurst et al., 2003; El Messari et al., 2004 \\
(Pyr ${ }^{1}$ )apelin-13 & Full agonist & $8.9-8.0$ & Hosoya et al., 2000; Medhurst et al., 2003; El Messari et al., 2004 \\
Apelin-13 & Full agonist & $9.2-8.8$ & Fan et al., 2003; Medhurst et al., 2003 \\
\hline
\end{tabular}

Kawamata et al., 2001; Medhurst et al., 2003). A similar distribution is shown by the peptide (Kawamata et al., 2001).

\section{B. Human}

Within the human CNS, apelin mRNA is present in all regions tested, with highest expression in the spinal cord, corpus callosum, amygdala, substantia nigra, and pituitary gland (Medhurst et al., 2003).

Peripheral apelin mRNA, like its receptor, is found at highest levels in the placenta, with lower levels in the heart, lung, and kidney (Medhurst et al., 2003). Apelin is present in a range of cell types within the placenta, lung, and kidney (De Falco et al., 2002) but has a restricted distribution within the cardiovascular system, being expressed only by vascular and endocardial endothelial cells (Kleinz and Davenport, 2004).

\section{Synthetic Agonists}

A number of synthetic apelin analogs have biological activity. Apelin-12 is the smallest C-terminal fragment to bind and activate the apelin receptor (El Messari et al., 2004), and any apelin fragment containing this 12 amino acid core maintains agonist function. Cyclic apelin analogs (Fig. 4) have been found to have binding and functional activity at the apelin receptor (Hamada et al., 2008; Macaluso et al., 2009), giving important structural insights into the apelin binding site. The first nonpeptidic agonist at the apelin receptor, E339-3D6, was reported by Iturrioz et al. (2009).

\section{Antagonists}

A small-molecule antagonist of the chemokine receptor CXCR4, ALX40-4C, has been shown to directly bind apelin receptors expressed in cell lines and to block ligand-induced receptor internalization and signaling. It

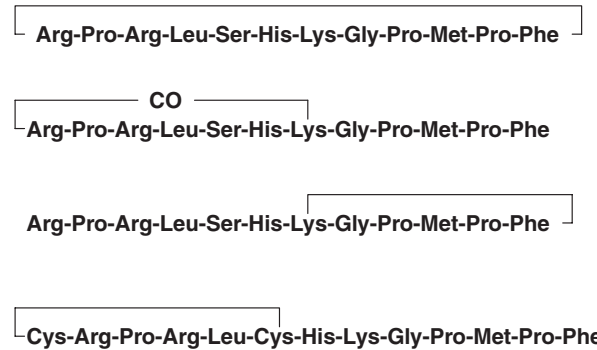

FIG. 4. Cyclic apelin analogs drawn from the sequences reported by Hamada et al. (2008) (a) and Macaluso et al. (2009) (b). also inhibits apelin receptor-mediated cell membrane fusion. This suggests that ALX40-4C is a nonspecific apelin receptor antagonist (Table 3) (Zhou et al., 2003).

The role of the C-terminal phenylalanine of the apelin peptides has been of particular interest since the discovery that the recently identified homolog of ACE, ACE2, cleaves this residue from apelin peptides. Apelin-13 with the C-terminal phenylalanine mutated to alanine [Apelin-13(F13A); Gln-Arg-Pro-Arg-LeuSer-His-Lys-Gly-Pro-Met-Pro-Ala] has been shown to act as an apelin-specific functional antagonist in rats in vivo, blocking the hypotensive effects of apelin-13 (Lee et al., 2005). However, no in vitro confirmation of its antagonist activity has been made, and there are conflicting reports as to the effect of alanine substitution at this position on the activity of apelins at the apelin receptor expressed in cell lines. De Mota et al. (2000) found that substitution of the C-terminal phenylalanine of $\left(\mathrm{Pyr}^{1}\right)$ apelin-13 for alanine abolished the agonist activity of this peptide at the rat apelin receptor expressed in CHO cells. However, two studies showed that substitution of the C-terminal phenylalanine for alanine in $\left(\mathrm{Pyr}^{1}\right)$ apelin-13 or apelin-13 had little effect on their affinity or agonist activity at the human apelin receptor expressed in human embryonic kidney 293 cells (Fan et al., 2003; Medhurst et al., 2003). Apelin-13(F13A) has been demonstrated to have comparable affinity and agonist activity at the native apelin receptor in human cardiovascular tissues in vitro (Pitkin et al., 2009), indicating that this peptide is a full agonist in man. The disparity of these reports may reflect species differences in the structure activity relationships of the human and rat apelin receptor.

\section{Radiolabeled Ligands}

A number of radiolabeled ligands for the apelin receptor have been synthesized based on the structure of the endogenous ligands (Table 4), but most are based on $\left(\mathrm{Pyr}^{1}\right)$ apelin-13. $\left[{ }^{125} \mathrm{I}\right]\left(\mathrm{Pyr}^{1}\right)$ apelin-13 binds to receptors in human left ventricle with a $K_{\mathrm{D}}$ of 0.35 $\mathrm{nM}$. It associates rapidly, with a half-time for association of $6 \mathrm{~min}$, and dissociates with a half-time for dissociation of $53 \mathrm{~min}$ (Katugampola et al., 2001). It is noteworthy that analogs of this radioligand have been made by others with modifications at position 75 . Hosoya et al. (2000) replaced the methionine at this position with norleucine to prevent possible oxidation 
TABLE 3

Actions and affinities of apelin receptor antagonists

\begin{tabular}{llcl}
\hline Ligand & \multicolumn{1}{c}{ Action } & Affinity $\left(\mathrm{p} K_{\mathrm{d}}\right)$ & Reference \\
\hline ALX40-4C & Nonspecific antagonist & 5.5 & Zhou et al., 2003 \\
Apelin-13(F13A) & Functional antagonist & N.D. & Lee et al., 2005 \\
\hline
\end{tabular}

N.D., not determined.

during the radiolabeling process, because they found oxidized $\left(\mathrm{Pyr}^{1}\right)$ apelin-13 to be inactive. The resulting radioligand, $\left.{ }^{125} \mathrm{I}\right]\left(\mathrm{Pyr}^{1}\right)\left[\mathrm{Nle}^{75}, \mathrm{Tyr}^{77}\right]$ apelin-13, is commercially available. Medhurst et al. (2003) oxidized the methionine at this position, because the unoxidized form of the radioligand was very unstable.

\section{Physiological Roles}

Since the discovery of apelin as the endogenous ligand for APJ in 1998, a number of physiological roles for the receptor have emerged, including regulation of cardiovascular function, fluid homeostasis, and the adipoinsular axis.

\section{A. Cardiovascular Roles}

An important role for the apelin system in cardiovascular regulation is supported by cardiovascular phenotypes in both the apelin receptor and apelin peptide knockout mouse (see section XIII). Apelin modulates vascular tone in vivo, causing a reduction in blood pressure when infused into rats (Lee et al., 2000; Reaux et al., 2001; Tatemoto et al., 2001; Cheng et al., 2003; Ishida et al., 2004; El Messari et al., 2004; Lee et al., 2005; Mitra et al., 2006; Iturrioz et al., 2007) and vasodilation of resistance vessels when infused into the human forearm (Japp et al., 2008), both responses mediated primarily by nitric oxide. In vitro, apelin causes vasodilation of human splanchnic artery, largely via a nitric oxide-dependent mechanism (Salcedo et al., 2007). Apelin also causes vasoconstriction of human saphenous vein (Katugampola et al., 2001) and mammary artery (Maguire et al., 2009) in vitro by a direct action on vascular smooth muscle. These data support a role for the apelin system in modulation of vascular tone, where apelin released from endothelial cells would act on apelin receptors on the endothelium to cause vasodilation or on underlying smooth muscle cells to cause vasoconstriction.

Apelin also modulates cardiac function. Apelin peptides have positive inotropic effects in rats (Berry et al.,
2004; Jia et al., 2006; Atluri et al., 2007) and mice (Ashley et al., 2005) in vivo. In vitro studies have demonstrated that apelins are potent positive inotropic agents by a direct action on cardiac tissue in rat (Szokodi et al., 2002; Dai et al., 2006; Farkasfalvi et al., 2007) and human (Maguire et al., 2009). It is noteworthy that apelins are the most potent endogenous inotropic agents yet reported in isolated cardiac tissue, with $\mathrm{EC}_{50}$ values of 40 to $125 \mathrm{pM}$ in human tissue (Maguire et al., 2009) and $33 \mathrm{pM}$ in rat tissue (Szokodi et al., 2002).

In addition, apelin is a potent angiogenic factor (Kasai et al., 2004; Cox et al., 2006) and mitogen of endothelial cells (Kasai et al., 2004; Masri et al., 2004) and vascular smooth muscle cells ( $\mathrm{Li}$ et al., 2008). Apelin and its receptor are required for normal cardiovascular development. In the frog, apelin and its receptor are required for normal heart morphology (Inui et al., 2006) and for angiogenesis of intersomitic vessels (Cox et al., 2006; Kälin et al., 2007). In the zebrafish, either an excess or deficit of apelin impairs the migration of anterior lateral plate mesoderm cells during gastrulation, such that the myocardial progenitos cells are not in the correct position to receive inductive signals required for differentiation, resulting in a deficiency of the heart (Scott et al., 2007; Zeng et al., 2007, Nornes et al., 2009). Mice lacking the apelin gene show retardation of retinal vascular development (Kasai et al., 2008) and narrow blood vessels in intersomitic vessels during embryogenesis (Kidoya et al., 2008), whereas APLNR(-/-) mice have cardiac developmental defects (Charo et al., 2009). It has recently been shown that apelin acts downstream of Cripto (official gene name $t d g f-1$ ) to specify murine embryonic stem cells toward the cardiac lineage (D'Aniello et al., 2009).

\section{B. Fluid Homeostasis}

The colocalization of apelin and its receptor with vasopressin in magnocellular neurons of the SON and PVN of the hypothalamus triggered investigation of

TABLE 4

Radiolabelled ligands of the apelin receptor

\begin{tabular}{|c|c|c|c|}
\hline Ligand & Affinity $\left(\mathrm{p} K_{\mathrm{D}}\right)$ & Expression System & Reference \\
\hline$\left[{ }^{125} \mathrm{I}\right]$ apelin-13 & N.D. & HEK-293 cells & Fan et al., 2003 \\
\hline$\left[{ }^{125} \mathrm{I}\right]\left(\mathrm{Pyr}^{1}\right)$ apelin-13 & $9.7-9.2$ & Human/Rat tissue & Katugampola et al., 2001; El Messari et al., 2004 \\
\hline$\left[{ }^{125} \mathrm{I}\right]\left(\mathrm{Pyr}^{1}\right)\left[\mathrm{Nle}^{75}, \mathrm{Tyr}^{77}\right]$ apelin-13 & $8.4-10.7$ & CHO-A10 cells/HEK-293 cells & Hosoya et al., 2000; Hashimoto et al., 2005 \\
\hline$\left[{ }^{3} \mathrm{H}\right]\left(\mathrm{Pyr}^{1}\right)\left[\operatorname{Met}(\mathrm{O})^{11}\right]$ apelin-13 & 8.6 & HEK-293 cells & Medhurst et al., 2003 \\
\hline$\left[{ }^{125} \mathrm{I}\right]\left[\mathrm{Nle}^{75}, \mathrm{Tyr}^{77}\right]$ apelin-36 & 11.2 & CHO-A10 cells & Kawamata et al., 2001 \\
\hline
\end{tabular}

N.D., not determined. 
their role in fluid homeostasis. Apelin, given to mice by intracerebroventricular injection, inhibits vasopressin neuron activity and vasopressin release, decreasing plasma vasopressin concentration and increasing diuresis (De Mota et al., 2004). Dehydration increases apelin (Reaux-Le Goazigo et al., 2004) and apelin receptor (O'Carroll and Lolait, 2003) expression and decreases vasopressin expression in rat magnocellular neurons (Reaux-Le Goazigo et al., 2004). In addition to its central effects, apelin has direct actions on the microvasculature of the kidney (Hus-Citharel et al., 2008). APLNR(-/-) mice have abnormal fluid homeostasis and altered responses to osmotic stress (Roberts et al., 2009; Roberts et al., 2010) (see section XIII). Osmotic stimuli have been show to exert opposing effects on plasma apelin and vasopressin in man; increased plasma osmolality increases plasma vasopressin and decreases plasma apelin, and vice versa (Azizi et al., 2008). However, the role of the apelin system in drinking behavior is unclear.

\section{Adipoinsular Axis}

Apelin is expressed and released by cultured adipocytes, identifying it as a novel adipokine (Boucher et al., 2005), and adipose tissue is a possible source of plasma apelin. Apelin expression in adipose tissue is regulated by factors such as fasting and refeeding (Boucher et al., 2005), insulin (Boucher et al., 2005; Wei et al., 2005), hypoxia (Glassford et al., 2007; Kunduzova et al., 2008), growth hormone (Kralisch et al., 2007), tumor necrosis factor $\alpha$ (Daviaud et al., 2006), and peroxisome proliferator-activated receptor $\gamma$ coactivator $1 \alpha$ (Mazzucotelli et al., 2008). Whereas insulin stimulates adipose apelin expression (Boucher et al., 2005; Wei et al., 2005), apelin inhibits insulin secretion (Sörhede Winzell et al., 2005), presenting an interesting interaction between the two systems.

There is evidence for a role for apelin regulation of adiposity, peripherally administered apelin causing no change in food intake (Sunter et al., 2003; Higuchi et al., 2007) but decreasing adiposity, possibly by up-regulating uncoupling proteins and increasing energy expenditure (Higuchi et al., 2007). However, investigation of the role of central apelin on food intake and body weight has yielded disparate results (Taheri et al., 2002; O'Shea et al., 2003; Sunter et al., 2003; Valle et al., 2008). Apelin may also be involved in vascularization of adipose tissue (Kunduzova et al., 2008).

\section{Other Roles}

There is evidence for a role for the apelin system in gastrointestinal function, with expression of apelin and its receptor in several areas of the gastrointestinal tract during embryonic development and adulthood in rodents (Wang et al., 2004; Susaki et al., 2005; Wang et al., 2009). Proposed functions include stimulation of gastric cell proliferation and cholecystokinin secretion (Wang et al., 2004) and regulation of gastric acid secretion (Lambrecht et al., 2006). Apelin is expressed in osteoblasts and may have a role in stimulating proliferation and suppressing apoptosis in this cell type (Xie et al., 2006; Tang et al., 2007; Xie et al., 2007). Apelin has also been shown to inhibit apoptosis in neurons in vitro (Zeng et al., 2010) and to have antinociceptive effects (Xu et al., 2009). It has also been suggested that apelin may have an immunomodulatory role (Habata et al., 1999; Horiuchi et al., 2003; Leeper et al., 2009).

\section{Pathophysiological Roles}

\section{A. Cardiovascular Disease}

A growing body of evidence links the apelin system with cardiovascular disease. A number of studies have noted changes in human plasma apelin levels in conditions of cardiac dysfunction, with sometimes conflicting results and reporting a very wide range of concentrations $(20-4000 \mathrm{pg} / \mathrm{ml})$ depending on the assay used and sample preparation. Overall, plasma apelin seems to rise in early heart failure (Chen et al., 2003) but to normalize or decrease in later stages (Chen et al., 2003; Chong et al., 2006; Miettinen et al., 2007). Treatments such as chronic resynchronization therapy and placement of a left ventricular assist device increase apelin peptide levels (Chen et al., 2003; Francia et al., 2007). Apelin receptor mRNA was found to be decreased in left ventricle from patients with idiopathic dilated cardiomyopathy (Földes et al., 2003). It is noteworthy that the apelin receptor is the most significantly up-regulated gene of $>12,000$ after mechanical offloading of failing myocardium (Chen et al., 2003). These data suggest that apelin may be up-regulated in early disease as a compensatory mechanism, increasing the force of contraction of the heart. Both apelin and its receptor may then be down-regulated later in disease when its positive inotropic effects would be detrimental, owing to the resultant increase in oxygen demand.

A beneficial role of apelin in heart failure is supported by data from animal models. Cardiac apelin is increased in response to hypoxia via hypoxia-inducible factor-1 (Ronkainen et al., 2007), and both apelin and its receptor are up-regulated in ischemic heart failure in rats (Atluri et al., 2007; Sheikh et al., 2008). Apelin protects against cardiac ischemia reperfusion injury (Simpkin et al., 2007; Zeng et al., 2009) and inhibits glucose deprivation induced cardiomyocyte apoptosis (Zhang et al., 2009c), suggesting that apelin may be up-regulated in response to cardiac hypoxia to protect the tissue from ischemia reperfusion injury.

The apelin system has recently been implicated in the pathogenesis of atherosclerosis by evidence from transgenic mouse models (see section XIII), although there are conflicting reports as to whether apelin signaling is beneficial or detrimental in these models. In man, apelin peptide is up-regulated in atherosclerotic coronary ar- 
tery (Pitkin et al., 2009), and both apelin and its receptor are up-regulated in aortic valve stenosis, a process that displays some hallmarks of atherosclerosis (Peltonen et al., 2009), supporting an involvement of the apelin system in human atherosclerosis. Apelin also prevents aortic aneurism formation in mice (Leeper et al., 2009).

A role for the apelin system in hypertension has also been proposed. Spontaneously hypertensive rats have decreased cardiovascular apelin receptor and apelin mRNA and protein compared with control rats. Exercise training or long-term all-trans retinoic acid treatment improves hypertension in line with an increase in apelin receptor and apelin expression (Zhong et al., 2005; Zhang et al., 2006), consistent with the predominantly hypotensive effect seen in healthy individuals and animals. Spontaneously hypertensive rats have increased apelin expression in the rostral ventrolateral medulla, and overexpression of apelin in this area causes chronic hypertension in normotensive rats (Zhang et al., 2009b). Some single-nucleotide polymorphisms (SNPs) in the gene encoding the apelin receptor $(A P L N R)$ and apelin peptide $(A P L N)$ are associated with hypertension (see section XII). There is also evidence for a role in pulmonary hypertension (Andersen et al., 2009; Falcão-Pires et al., 2009) and portal hypertension (Tiani et al., 2009). It is noteworthy that apelin is able to cause vasodilation by a prostanoid-dependent mechanism in blood vessels from patients with atherosclerotic heart disease (Maguire et al., 2009). This suggests that apelin may have beneficial vasodilatory effects even in patient groups that display a degree of endothelial dysfunction.

The apelin system is proposed to have a role in pathophysiological angiogenesis, contributing to portosystemic collateralization and splanchnic neovascularization in portal hypertensive rats (Tiani et al., 2009), neoangiogenesis in liver cirrhosis (Principe et al., 2008), and tumor neoangiogenesis (Kälin et al., 2007; Sorli et al., 2007). However, angiogenic effects (Eyries et al., 2008) and induction of larger nonleaky vessels by apelin (Kidoya et al., 2010) appear to be beneficial in recovery from ischemia.

\section{B. Obesity and Diabetes}

Plasma apelin is positively correlated with body mass index in humans (Heinonen et al., 2005), and increased plasma and adipose tissue apelin expression in obese patients can be reversed by hypocaloric diet associated with weight loss (Castan-Laurell et al., 2008). However in mouse models of obesity, insulin level, rather than adiposity, is the major determinant of increased apelin expression (Boucher et al., 2005). This suggests that apelin expression may be increased in response to hyperinsulinemia associated with obesity rather than to obesity itself, although investigation of the effect of type 2 diabetes mellitus on plasma apelin has yielded disparate results ( $\mathrm{Li}$ et al., 2006; Erdem et al., 2008).
The up-regulation of apelin in obesity may be beneficial in metabolic syndrome because peripheral apelin treatment improves glucose tolerance and enhances glucose utilization in obese insulin-resistant mice (Dray et al., 2008); conversely, apelin knockout mice have reduced insulin sensitivity (Yue et al., 2010). Apelin also decreases body adiposity, without altering food intake, in obese mice by increasing the expression of uncoupling proteins and energy expenditure (Higuchi et al., 2007). The up-regulation of apelin in obesity may also have beneficial cardiovascular effects; limiting hypertension and increasing cardiac contractility (see section XI.A).

\section{Other Roles}

Roles for the apelin system in cardiovascular disease and obesity, conditions associated with inflammation, have raised interest in a possible connection between apelin and inflammation. Apelin expression is induced by inflammatory mediators, such as tumor necrosis factor $\alpha$ (Daviaud et al., 2006), interleukin-6, and interferon- $\gamma$ (Han et al., 2008) and plasma apelin levels correlate with markers of inflammation (Malyszko et al., 2008). It is possible that upregulation of apelin in response to inflammation is a compensatory mechanism to limit the onset of metabolic disorders, such as insulin resistance and cardiovascular dysfunction.

The apelin system has also been suggested to be involved in HIV infection of CD4 positive cells (Choe et al., 1998; Edinger et al., 1998; Zhang et al., 1998), gastrointestinal disorders (Han et al., 2007), liver cirrhosis (Principe et al., 2008), and obstructive sleep apnea (Henley et al., 2009).

\section{Single-Nucleotide Polymorphisms}

A number of SNPs within the gene encoding the apelin receptor $(A P L N R)$ are associated with cardiovascular disease risk. The G212A variant is associated with slower heart failure progression (Sarzani et al., 2007), whereas a SNP in the 5' flanking region is associated with susceptibility to brain infarction (Hata et al., 2007). Three SNPs within APLNR, and two in the gene encoding apelin $(A P L N)$, have been found to be associated with hypertension (Li et al., 2009), and a number of SNPs in APLNR were associated with blood pressure responses to dietary sodium intervention (Zhao et al., 2010 ) in Han Chinese. In addition, one SNP in APLN is associated with fasting plasma glucose levels in Han Chinese male subjects (Zhang et al., 2009a).

\section{Knockout Mouse Models}

Mice lacking the gene encoding the apelin receptor $[A P L N R(-/-)]$ are not born in the expected Mendelian ratio (Charo et al., 2009). They have normal baseline blood pressure and heart rate but lack the hypotensive response to apelin seen in wild-type mice. In addition, 
angiotensin II produces a greater pressor effect in apelin receptor-deficient mice compared with wildtype mice, and double mutant mice, lacking both the apelin receptor and $\mathrm{AT}_{1 \mathrm{a}}$, have a higher baseline blood pressure than mice lacking $\mathrm{AT}_{1 \mathrm{a}}$ only (Ishida et al., 2004). These data suggest a role for the apelin receptor in blood pressure regulation, particularly in opposing the effects of angiotensin II. APLNR(-/-) mice show cardiac developmental defects and modest decrements in contractile function under basal conditions, but under exercise stress, they have strikingly reduced exercise capacity (Charo et al., 2009), supporting a role for the apelin receptor in cardiac function.

It is noteworthy that apelin receptor-deficient mice on an $\mathrm{ApoE}(-/-)$ background have a reduced atherosclerotic burden compared with APLNR(+/+) ApoE(-/-) mice (Hashimoto et al., 2007). Likewise, apelin knockout mice show decreased neointima formation in a carotid ligation model (Kojima et al., 2010), implying that activation of the apelin receptor is detrimental in atherosclerosis. This contrasts with the findings of Chun et al. (2008), where apelin signaling opposed angiotensin II-induced atherosclerosis in $\mathrm{ApoE}(-/-)$ mice. APLNR(-/-) mice have been shown to have abnormal fluid homeostasis, drinking significantly less water, showing an inability to concentrate their urine to the same extent as wild-type mice (Roberts et al., 2009) and having altered responses to osmotic stress (Roberts et al., 2010), supporting a role for the apelin receptor in fluid homeostasis.

Apelin knockout mice are viable, fertile, appear healthy, and have normal body weight, normal water and food intake, and normal heart rates and heart morphology (Kuba et al., 2007; Charo et al., 2009). However, similar to APLNR(-/-) mice, these mice have slightly impaired cardiac function under basal conditions and markedly decreased exercise capacity (Charo et al., 2009). They also develop progressive impairment of cardiac contractility with age and present with more severely impaired heart function in response to pressure overload than wild-type mice (Kuba et al., 2007). This indicates that apelin is important in the maintenance of cardiac function in conditions of exercise stress, pressure overload and aging. Apelin-deficient mice also show impaired retinal vascularization and ocular development (Kasai et al., 2008) and narrow blood vessels in intersomitic vessels during embryogenesis (Kidoya et al., 2008). In addition, apelin knockout mice have diminished insulin sensitivity (Yue et al., 2010).

\section{Conclusion}

In conclusion, since the pairing of the apelin receptor with its endogenous ligand apelin in 1998, a number of physiological and pathophysiological roles have emerged for this receptor, including modulation of the cardiovascular system, fluid homeostasis, and the adipoinsular axis. Development of additional pharmacological tools, particularly a competitive antagonist, and further investigation of the roles of endogenous apelin will aid validation of this system as a drug target in a range of conditions.

Acknowledgments. This work was supported by the British Heart Foundation [Grants PS/02/001, PG/09/050/27734, FS/06/017].

\section{REFERENCES}

Andersen CU, Markvardsen LH, Hilberg O, and Simonsen U (2009) Pulmonary apelin levels and effects in rats with hypoxic pulmonary hypertension. Respir Med 103:1663-1671.

Ashley EA, Powers J, Chen M, Kundu R, Finsterbach T, Caffarelli A, Deng A Eichhorn J, Mahajan R, Agrawal R, et al. (2005) The endogenous peptide apelin potently improves cardiac contractility and reduces cardiac loading in vivo. Cardiovasc Res 65:73-82.

Atluri P, Morine KJ, Liao GP, Panlilio CM, Berry MF, Hsu VM, Hiesinger W, Cohen JE, and Joseph Woo Y (2007) Ischemic heart failure enhances endogenous myocardial apelin and APJ receptor expression. Cell Mol Biol Lett 12:127-138.

Azizi M, Iturrioz X, Blanchard A, Peyrard S, De Mota N, Chartrel N, Vaudry H, Corvol P, and Llorens-Cortes C (2008) Reciprocal regulation of plasma apelin and vasopressin by osmotic stimuli. J Am Soc Nephrol 19:1015-1024.

Bełtowski J (2006) Apelin and visfatin: unique "beneficial" adipokines upregulated in obesity? Med Sci Monit 12:RA112-RA119.

Berry MF, Pirolli TJ, Jayasankar V, Burdick J, Morine KJ, Gardner TJ, and Woo YJ (2004) Apelin has in vivo inotropic effects on normal and failing hearts. Circulation 110:II187-II193.

Boucher J, Masri B, Daviaud D, Gesta S, Guigné C, Mazzucotelli A, Castan-Laurell I, Tack I, Knibiehler B, Carpéné C, et al. (2005) Apelin, a newly identified adipokine up-regulated by insulin and obesity. Endocrinology 146:1764-1771.

Brown CH, Ruan M, Scott V, Tobin VA, and Ludwig M (2008) Multi-factorial somato-dendritic regulation of phasic spike discharge in vasopressin neurons. Prog Brain Res 170:219-228.

Bundzikova J, Pirnik Z, Zelena D, Mikkelsen JD, and Kiss A (2008) Response of substances co-expressed in hypothalamic magnocellular neurons to osmotic challenges in normal and Brattleboro rats. Cell Mol Neurobiol 28:1033-1047.

Carpéné C, Dray C, Attané C, Valet P, Portillo MP, Churruca I, Milagro FI, and Castan-Laurell I (2007) Expanding role for the apelin/APJ system in physiopathology. J Physiol Biochem 63:359-373.

Castan-Laurell I, Boucher J, Dray C, Daviaud D, Guigné C, and Valet P (2005) Apelin, a novel adipokine over-produced in obesity: friend or foe? Mol Cell Endocrinol 245:7-9.

Castan-Laurell I, Vítkova M, Daviaud D, Dray C, Kováciková M, Kovacova Z, Hejnova J, Stich V, and Valet P (2008) Effect of hypocaloric diet-induced weight loss in obese women on plasma apelin and adipose tissue expression of apelin and APJ. Eur J Endocrinol 158:905-910.

Chandrasekaran B, Dar O, and McDonagh T (2008) The role of apelin in cardiovascular function and heart failure. Eur J Heart Fail 10:725-732.

Charo DN, Ho M, Fajardo G, Kawana M, Kundu RK, Sheikh AY, Finsterbach TP, Leeper NJ, Ernst KV, Chen MM, et al. (2009) Endogenous regulation of cardiovascular function by apelin-APJ. Am J Physiol Heart Circ Physiol 297:H1904-13.

Chen MM, Ashley EA, Deng DX, Tsalenko A, Deng A, Tabibiazar R, Ben-Dor A Fenster B, Yang E, King JY, et al. (2003) Novel role for the potent endogenous inotrope apelin in human cardiac dysfunction. Circulation 108:1432-1439.

Cheng X, Cheng XS, and Pang CC (2003) Venous dilator effect of apelin, an endogenous peptide ligand for the orphan APJ receptor, in conscious rats. Eur J Pharmacol 470:171-175.

Choe H, Farzan M, Konkel M, Martin K, Sun Y, Marcon L, Cayabyab M, Berman M, Dorf ME, Gerard N, et al. (1998) The orphan seven-transmembrane receptor apj supports the entry of primary T-cell-line-tropic and dualtropic human immunodeficiency virus type 1. J Virol 72:6113-6118.

Chong KS, Gardner RS, Morton JJ, Ashley EA, and McDonagh TA (2006) Plasma concentrations of the novel peptide apelin are decreased in patients with chronic heart failure. Eur $J$ Heart Fail 8:355-360.

Chun HJ, Ali ZA, Kojima Y, Kundu RK, Sheikh AY, Agrawal R, Zheng L, Leeper NJ, Pearl NE, Patterson AJ, et al. (2008) Apelin signaling antagonizes Ang II effects in mouse models of atherosclerosis. J Clin Invest 118:3343-3354.

Cox CM, D'Agostino SL, Miller MK, Heimark RL, and Krieg PA (2006) Apelin, the ligand for the endothelial G-protein-coupled receptor, APJ, is a potent angiogenic factor required for normal vascular development of the frog embryo. Dev Biol 296:177-189.

Dai T, Ramirez-Correa G, and Gao WD (2006) Apelin increases contractility in failing cardiac muscle. Eur J Pharmacol 553:222-228.

D'Aniello C, Lonardo E, Iaconis S, Guardiola O, Liguoro AM, Liguori GL, Autiero M, Carmeliet P, and Minchiotti G (2009) G protein-coupled receptor APJ and its ligand apelin act downstream of Cripto to specify embryonic stem cells toward the cardiac lineage through extracellular signal-regulated kinase/p70S6 kinase signaling pathway. Circ Res 105:231-238

Davenport AP, Pitkin SL, and Maguire JJ (2007) Apelins, in Encyclopedic Reference of Molecular Pharmacology (Offermanns S and Rosenthal W eds) pp 201-206, Springer, Berlin.

Davenport AP and Kleinz MJ (2008) Apelin receptor. IUPHAR database (IUPHAR DB). Available at http://www.iuphar-db.org/DATABASE/FamilyMenuForward? familyId $=7$.

Daviaud D, Boucher J, Gesta S, Dray C, Guigne C, Quilliot D, Ayav A, Ziegler O, 
Carpene C, Saulnier-Blache JS, et al. (2006) TNFalpha up-regulates apelin expression in human and mouse adipose tissue. FASEB $J$ 20:1528-1530.

De Falco M, De Luca L, Onori N, Cavallotti I, Artigiano F, Esposito V, De Luca B, Laforgia V, Groeger AM, and De Luca A (2002) Apelin expression in normal human tissues. In Vivo 16:333-336.

De Mota N, Lenkei Z, and Llorens-Cortès C (2000) Cloning, pharmacological characterization and brain distribution of the rat apelin receptor. Neuroendocrinology 72:400-407.

De Mota N, Reaux-Le Goazigo A, El Messari S, Chartrel N, Roesch D, Dujardin C, Kordon C, Vaudry H, Moos F, and Llorens-Cortes C (2004) Apelin, a potent diuretic neuropeptide counteracting vasopressin actions through inhibition of vasopressin neuron activity and vasopressin release. Proc Natl Acad Sci USA 101: 10464-10469.

Dray C, Knauf C, Daviaud D, Waget A, Boucher J, Buléon M, Cani PD, Attané C, Guigné C, Carpéné C, et al. (2008) Apelin stimulates glucose utilization in normal and obese insulin-resistant mice. Cell Metab 8:437-445.

Edinger AL, Hoffman TL, Sharron M, Lee B, Yi Y, Choe W, Kolson DL, Mitrovic B, Zhou Y, Faulds D, et al. (1998) An orphan seven-transmembrane domain receptor expressed widely in the brain functions as a coreceptor for human immunodeficiency virus type 1 and simian immunodeficiency virus. $J$ Virol 72:7934-7940.

El Messari S, Iturrioz X, Fassot C, De Mota N, Roesch D, and Llorens-Cortes C (2004) Functional dissociation of apelin receptor signaling and endocytosis: implications for the effects of apelin on arterial blood pressure. J Neurochem 90:12901301.

Erdem G, Dogru T, Tasci I, Sonmez A, and Tapan S (2008) Low plasma apelin levels in newly diagnosed type 2 diabetes mellitus. Exp Clin Endocrinol Diabetes 116: $289-292$.

Eyries M, Siegfried G, Ciumas M, Montagne K, Agrapart M, Lebrin F, and Soubrier F (2008) Hypoxia-induced apelin expression regulates endothelial cell proliferation and regenerative angiogenesis. Circ Res 103:432-440.

Falcão-Pires I, Gonçalves N, Henriques-Coelho T, Moreira-Gonçalves D, RonconAlbuquerque R Jr, and Leite-Moreira AF (2009) Apelin decreases myocardial injury and improves right ventricular function in monocrotaline-induced pulmonary hypertension. Am J Physiol Heart Circ Physiol 296:H2007-14.

Fan X, Zhou N, Zhang X, Mukhtar M, Lu Z, Fang J, DuBois GC, and Pomerantz RJ (2003) Structural and functional study of the apelin-13 peptide, an endogenous ligand of the HIV-1 coreceptor, APJ. Biochemistry 42:10163-10168.

Farkasfalvi K, Stagg MA, Coppen SR, Siedlecka U, Lee J, Soppa GK, Marczin N, Szokodi I, Yacoub MH, and Terracciano CM (2007) Direct effects of apelin on cardiomyocyte contractility and electrophysiology. Biochem Biophys Res Commun 357:889-895.

Földes G, Horkay F, Szokodi I, Vuolteenaho O, Ilves M, Lindstedt KA, Mäyränpää M, Sármán B, Seres L, Skoumal R, et al. (2003) Circulating and cardiac levels of apelin, the novel ligand of the orphan receptor APJ, in patients with heart failure. Biochem Biophys Res Commun 308:480-485

Francia P, Salvati A, Balla C, De Paolis P, Pagannone E, Borro M, Gentile G, Simmaco M, De Biase L, and Volpe M (2007) Cardiac resynchronization therapy increases plasma levels of the endogenous inotrope apelin. Eur $J$ Heart Fail 9:306-309.

Glassford AJ, Yue P, Sheikh AY, Chun HJ, Zarafshar S, Chan DA, Reaven GM, Quertermous T, and Tsao PS (2007) HIF-1 regulates hypoxia- and insulin-induced expression of apelin in adipocytes. Am J Physiol Endocrinol Metab 293:E1590E1596.

Habata Y, Fujii R, Hosoya M, Fukusumi S, Kawamata Y, Hinuma S, Kitada C, Nishizawa N, Murosaki S, Kurokawa T, et al. (1999) Apelin, the natural ligand of the orphan receptor APJ, is abundantly secreted in the colostrum. Biochim Biophys Acta 1452:25-35.

Hamada J, Kimura J, Ishida J, Kohda T, Morishita S, Ichihara S, and Fukamizu A (2008) Evaluation of novel cyclic analogues of apelin. Int J Mol Med 22:547-552.

Han S, Wang G, Qiu S, de la Motte C, Wang HQ, Gomez G, Englander EW, and Greeley GH Jr (2007) Increased colonic apelin production in rodents with experimental colitis and in humans with IBD. Regul Pept 142:131-137.

Han S, Wang G, Qi X, Englander EW, and Greeley GH Jr (2008) Involvement of a Stat3 binding site in inflammation-induced enteric apelin expression. Am J Physiol Gastrointest Liver Physiol 295:G1068-78.

Hashimoto T, Kihara M, Imai N, Yoshida S, Shimoyamada H, Yasuzaki H, Ishida J, Toya Y, Kiuchi Y, Hirawa N, et al. (2007) Requirement of apelin-apelin receptor system for oxidative stress-linked atherosclerosis. Am J Pathol 171:1705-1712.

Hashimoto Y, Ishida J, Yamamoto R, Fujiwara K, Asada S, Kasuya Y, Mochizuki N, and Fukamizu A (2005) G protein-coupled APJ receptor signaling induces focal adhesion formation and cell motility. Int J Mol Med 16:787-792.

Hata J, Matsuda K, Ninomiya T, Yonemoto K, Matsushita T, Ohnishi Y, Saito S, Kitazono T, Ibayashi S, Iida M, et al. (2007) Functional SNP in an Sp1-binding site of AGTRL1 gene is associated with susceptibility to brain infarction. Hum Mol Genet 16:630-639.

Heinonen MV, Purhonen AK, Miettinen P, Pääkkönen M, Pirinen E, Alhava E, Akerman K, and Herzig KH (2005) Apelin, orexin-A and leptin plasma levels in morbid obesity and effect of gastric banding. Regul Pept 130:7-13.

Henley DE, Buchanan F, Gibson R, Douthwaite JA, Wood SA, Woltersdorf WW, Catterall JR, and Lightman SL (2009) Plasma apelin levels in obstructive sleep apnea and the effect of continuous positive airway pressure therapy. $J$ Endocrinol 203:181-188

Higuchi K, Masaki T, Gotoh K, Chiba S, Katsuragi I, Tanaka K, Kakuma T, and Yoshimatsu H (2007) Apelin, an APJ receptor ligand, regulates body adiposity and favors the messenger ribonucleic acid expression of uncoupling proteins in mice. Endocrinology 148:2690-2697.

Hinuma S, Onda H, and Fujino M (1999) The quest for novel bioactive peptides utilizing orphan seven-transmembrane-domain receptors. J Mol Med 77:495-504.

Horiuchi Y, Fujii T, Kamimura Y, and Kawashima K (2003) The endogenous, immunologically active peptide apelin inhibits lymphocytic cholinergic activity during immunological responses. $J$ Neuroimmunol 144:46-52.
Hosoya M, Kawamata Y, Fukusumi S, Fujii R, Habata Y, Hinuma S, Kitada C, Honda S, Kurokawa T, Onda H, et al. (2000) Molecular and functional characteristics of APJ. Tissue distribution of mRNA and interaction with the endogenous ligand apelin. J Biol Chem 275:21061-21067.

Hus-Citharel A, Bouby N, Frugière A, Bodineau L, Gasc JM, and Llorens-Cortes C (2008) Effect of apelin on glomerular hemodynamic function in the rat kidney. Kidney Int 74:486-494.

Inui M, Fukui A, Ito Y, and Asashima M (2006) Xapelin and Xmsr are required for cardiovascular development in Xenopus laevis. Dev Biol 298:188-200.

Ishida J, Hashimoto T, Hashimoto Y, Nishiwaki S, Iguchi T, Harada S, Sugaya T, Matsuzaki H, Yamamoto R, Shiota N, et al. (2004) Regulatory roles for APJ, a seven-transmembrane receptor related to angiotensin-type 1 receptor in blood pressure in vivo. J Biol Chem 279:26274-26279.

Iturrioz X, El Messari S, De Mota N, Fassot C, Alvear-Perez R, Maigret B, and Llorens-Cortes $\mathrm{C}$ (2007) [Functional dissociation between apelin receptor signaling and endocytosis: implications for the effects of apelin on arterial blood pressure.] Arch Mal Coeur Vaiss 100:704-708.

Iturrioz X, Alvear-Perez R, De Mota N, Franchet C, Guillier F, Leroux V, Dabire H, Le Jouan M, Chabane H, Gerbier R, et al. (2009) Identification and pharmacolog ical properties of E339-3D6, the first nonpeptidic apelin receptor agonist. FASEB $J$ doi:10.1096/fj.09-140715.

Japp AG, Cruden NL, Amer DA, Li VK, Goudie EB, Johnston NR, Sharma S, Neilson I, Webb DJ, Megson IL, et al. (2008) Vascular effects of apelin in vivo in man. J Am Coll Cardiol 52:908-913.

Japp AG and Newby DE (2008) The apelin-APJ system in heart failure: pathophysiologic relevance and therapeutic potential. Biochem Pharmacol 75:1882-1892.

Jia YX, Pan CS, Zhang J, Geng B, Zhao J, Gerns H, Yang J, Chang JK, Tang CS, and Qi YF (2006) Apelin protects myocardial injury induced by isoproterenol in rats Regul Pept 133:147-154.

Kalea AZ and Batlle D (2010) Apelin and ACE2 in cardiovascular disease. Curr Opin Investig Drugs 11:273-282.

Kälin RE, Kretz MP, Meyer AM, Kispert A, Heppner FL, and Brändli AW (2007) Paracrine and autocrine mechanisms of apelin signaling govern embryonic and tumor angiogenesis. Dev Biol 305:599-614.

Kasai A, Shintani N, Oda M, Kakuda M, Hashimoto H, Matsuda T, Hinuma S, and Baba A (2004) Apelin is a novel angiogenic factor in retinal endothelial cells. Biochem Biophys Res Commun 325:395-400.

Kasai A, Shintani N, Kato H, Matsuda S, Gomi F, Haba R, Hashimoto H, Kakuda M, Tano Y, and Baba A (2008) Retardation of retinal vascular development in apelindeficient mice. Arterioscler Thromb Vasc Biol 28:1717-1722.

Katugampola SD, Maguire JJ, Matthewson SR, and Davenport AP (2001) [ $\left.{ }^{125} \mathrm{I}\right]-$ $\left(\mathrm{Pyr}^{1}\right)$ Apelin-13 is a novel radioligand for localizing the APJ orphan receptor in human and rat tissues with evidence for a vasoconstrictor role in man. $\mathrm{Br} J$ Pharmacol 132:1255-1260.

Kawamata Y, Habata Y, Fukusumi S, Hosoya M, Fujii R, Hinuma S, Nishizawa N, Kitada C, Onda H, Nishimura O, et al. (2001) Molecular properties of apelin: tissue distribution and receptor binding. Biochim Biophys Acta 1538:162-171.

Kidoya H, Ueno M, Yamada Y, Mochizuki N, Nakata M, Yano T, Fujii R, and Takakura N (2008) Spatial and temporal role of the apelin/APJ system in the caliber size regulation of blood vessels during angiogenesis. EMBO J 27:522-534

Kidoya H, Naito H, and Takakura N (2010) Apelin induces enlarged and nonleaky blood vessels for functional recovery from ischemia. Blood 115:3166-3174.

Kleinz MJ and Davenport AP (2004) Immunocytochemical localization of the endogenous vasoactive peptide apelin to human vascular and endocardial endothelial cells. Regul Pept 118:119-125.

Kleinz MJ and Davenport AP (2005) Emerging roles of apelin in biology and medicine. Pharmacol Ther 107:198-211.

Kleinz MJ, Skepper JN, and Davenport AP (2005) Immunocytochemical localisation of the apelin receptor, APJ, to human cardiomyocytes, vascular smooth muscle and endothelial cells. Regul Pept 126:233-240.

Kojima Y, Kundu R, Cox CM, Leeper NJ, Anderson JA, Chun HJ, Ali ZA, Ashley EA Krieg PA, and Quertermous T (2010) Upregulation of the apelin-APJ pathway promotes neointima formation in the carotid ligation model in mouse. Cardiovas Res doi:10.1093/cvr/cvq052.

Kralisch S, Lossner U, Bluher M, Paschke R, Stumvoll M, and Fasshauer M (2007) Growth hormone induces apelin mRNA expression and secretion in mouse 3T3-L1 adipocytes. Regul Pept 139:84-89.

Kuba K, Zhang L, Imai Y, Arab S, Chen M, Maekawa Y, Leschnik M, Leibbrandt A, Markovic M, Makovic M, et al. (2007) Impaired heart contractility in Apelin gene-deficient mice associated with aging and pressure overload. Circ Res 101: e32-42.

Kunduzova O, Alet N, Delesque-Touchard N, Millet L, Castan-Laurell I, Muller C, Dray C, Schaeffer P, Herault JP, Savi P, et al. (2008) Apelin/APJ signaling system: a potential link between adipose tissue and endothelial angiogenic processes. FASEB J 22:4146-4153.

Ladeiras-Lopes R, Ferreira-Martins J, and Leite-Moreira AF (2008) The apelinergic system: the role played in human physiology and pathology and potential therapeutic applications. Arq Bras Cardiol 90:343-349.

Lambrecht NW, Yakubov I, Zer C, and Sachs G (2006) Transcriptomes of purified gastric ECL and parietal cells: identification of a novel pathway regulating acid secretion. Physiol Genomics 25:153-165.

Lee DK, Cheng R, Nguyen T, Fan T, Kariyawasam AP, Liu Y, Osmond DH, George SR, and O'Dowd BF (2000) Characterization of apelin, the ligand for the APJ receptor. J Neurochem 74:34-41.

Lee DK, Saldivia VR, Nguyen T, Cheng R, George SR, and O'Dowd BF (2005) Modification of the terminal residue of apelin-13 antagonizes its hypotensive action. Endocrinology 146:231-236.

Lee DK, George SR, and O'Dowd BF (2006) Unravelling the roles of the apelin system: prospective therapeutic applications in heart failure and obesity. Trends Pharmacol Sci 27:190-194.

Leeper NJ, Tedesco MM, Kojima Y, Schultz GM, Kundu RK, Ashley EA, Tsao PS, 
Dalman RL, and Quertermous T (2009) Apelin prevents aortic aneurysm formation by inhibiting macrophage inflammation. Am J Physiol Heart Circ Physio 296:H1329-1335.

Li L, Yang G, Li Q, Tang Y, Yang M, Yang H, and Li K (2006) Changes and relations of circulating visfatin, apelin, and resistin levels in normal, impaired glucose tolerance, and type 2 diabetic subjects. Exp Clin Endocrinol Diabetes 114:544548

Li F, Li L, Qin X, Pan W, Feng F, Chen F, Zhu B, Liao D, Tanowitz H, Albanese C, et al. (2008) Apelin-induced vascular smooth muscle cell proliferation: the regulation of cyclin D1. Front Biosci 13:3786-3792.

Li WW, Niu WQ, Zhang Y, Wu S, Gao PJ, and Zhu DL (2009) Family-based analysis of apelin and AGTRL1 gene polymorphisms with hypertension in Han Chinese. J Hypertens 27:1194-1201.

Llorens-Cortes C and Moos F (2008) Opposite potentiality of hypothalamic coexpressed neuropeptides, apelin and vasopressin in maintaining body-fluid homeostasis. Prog Brain Res 170:559-570.

Macaluso NJ, Pitkin SL, Sanderson PN, Davenport AP, Glen RC (2009) Development and characterization of cyclic analogs of apelin-13 through replica-exchange mo lecular dynamics and experimental validation; COMP 182; in 237th ACS National Meeting; 2009 March 22-26; Salt Lake City, UT. American Chemical Society, Washington DC. Available at http://oasys2.confex.com/acs/237nm/techprogram/ P1240153.HTM.

Maguire JJ, Kleinz MJ, Pitkin SL, and Davenport AP (2009) [Pyr1]apelin-13 identified as the predominant apelin isoform in the human heart: vasoactive mechanisms and inotropic action in disease. Hypertension 54:598-604.

Malyszko J, Malyszko JS, Pawlak K, Wolczynski S, and Mysliwiec M (2008) Apelin, a novel adipocytokine, in relation to endothelial function and inflammation in kidney allograft recipients. Transplant Proc 40:3466-3469.

Masri B, Lahlou H, Mazarguil H, Knibiehler B, and Audigier Y (2002) Apelin (65-77) activates extracellular signal-regulated kinases via a PTX-sensitive G protein. Biochem Biophys Res Commun 290:539-545.

Masri B, Morin N, Cornu M, Knibiehler B, and Audigier Y (2004) Apelin (65-77) activates p70 $\mathrm{S} 6$ kinase and is mitogenic for umbilical endothelial cells. FASEB 18:1909-1911.

Masri B, Knibiehler B, and Audigier Y (2005) Apelin signalling: a promising pathway from cloning to pharmacology. Cell Signal 17:415-426.

Matsumoto M, Hidaka K, Akiho H, Tada S, Okada M, and Yamaguchi T (1996) Low stringency hybridization study of the dopamine D4 receptor revealed D4-like mRNA distribution of the orphan seven-transmembrane receptor, APJ, in human brain. Neurosci Lett 219:119-122.

Mazzucotelli A, Ribet C, Castan-Laurell I, Daviaud D, Guigné C, Langin D, and Valet P (2008) The transcriptional co-activator PGC-1alpha up regulates apelin in human and mouse adipocytes. Regul Pept 150:33-37.

Medhurst AD, Jennings CA, Robbins MJ, Davis RP, Ellis C, Winborn KY, Lawrie KW, Hervieu G, Riley G, Bolaky JE, et al. (2003) Pharmacological and immunohistochemical characterization of the APJ receptor and its endogenous ligand apelin. J Neurochem 84:1162-1172.

Miettinen KH, Magga J, Vuolteenaho O, Vanninen EJ, Punnonen KR, Ylitalo K, Tuomainen P, and Peuhkurinen KJ (2007) Utility of plasma apelin and other indices of cardiac dysfunction in the clinical assessment of patients with dilated cardiomyopathy. Regul Pept 140:178-184.

Mitra A, Katovich MJ, Mecca A, and Rowland NE (2006) Effects of central and peripheral injections of apelin on fluid intake and cardiovascular parameters in rats. Physiol Behav 89:221-225.

Nornes S, Tucker B, and Lardelli M (2009) Zebrafish aplnra functions in epiboly. BMC Res Notes 2:231.

O'Carroll AM, Selby TL, Palkovits M, and Lolait SJ (2000) Distribution of mRNA encoding B78/apj, the rat homologue of the human APJ receptor, and its endogenous ligand apelin in brain and peripheral tissues. Biochim Biophys Acta 1492 $72-80$

O'Carroll AM and Lolait SJ (2003) Regulation of rat APJ receptor messenger ribonucleic acid expression in magnocellular neurones of the paraventricular and supraopric nuclei by osmotic stimuli. J Neuroendocrinol 15:661-666.

O'Dowd BF, Heiber M, Chan A, Heng HH, Tsui LC, Kennedy JL, Shi X, Petronis A George SR, and Nguyen T (1993) A human gene that shows identity with the gen encoding the angiotensin receptor is located on chromosome 11. Gene 136:355-360.

O'Shea M, Hansen MJ, Tatemoto K, and Morris MJ (2003) Inhibitory effect of apelin-12 on nocturnal food intake in the rat. Nutr Neurosci 6:163-167.

Peltonen T, Näpänkangas J, Vuolteenaho O, Ohtonen P, Soini Y, Juvonen T, Satta J, Ruskoaho H, and Taskinen P (2009) Apelin and its receptor APJ in human aortic valve stenosis. J Heart Valve Dis 18:644-652.

Pitkin SL, Maguire JJ, Kuc RE, and Davenport AP (2010) Modulation of the apelin/ APJ system in heart failure and atherosclerosis in man. $\mathrm{Br}$ J Pharmacol doi: 10.1111/j.1476-5381.2010.00821.x

Principe A, Melgar-Lesmes P, Fernández-Varo G, del Arbol LR, Ros J, Morales-Ruiz M, Bernardi M, Arroyo V, and Jiménez W (2008) The hepatic apelin system: a new therapeutic target for liver disease. Hepatology 48:1193-1201.

Quazi R, Palaniswamy C, and Frishman WH (2009) The emerging role of apelin in cardiovascular disease and health. Cardiol Rev 17:283-286.

Rayalam S, Della-Fera MA, Krieg PA, Cox CM, Robins A, and Baile CA (2008) A putative role for apelin in the etiology of obesity. Biochem Biophys Res Commun 368:815-819.

Reaux A, De Mota N, Skultetyova I, Lenkei Z, El Messari S, Gallatz K, Corvol P, Palkovits M, and Llorens-Cortès C (2001) Physiological role of a novel neuropeptide, apelin, and its receptor in the rat brain. J Neurochem 77:1085-1096.

Reaux A, Gallatz K, Palkovits M, and Llorens-Cortes C (2002) Distribution of apelin-synthesizing neurons in the adult rat brain. Neuroscience 113:653-662.

Reaux-Le Goazigo A, Morinville A, Burlet A, Llorens-Cortes C, and Beaudet A (2004) Dehydration-induced cross-regulation of apelin and vasopressin immunoreactivity levels in magnocellular hypothalamic neurons. Endocrinology 145:4392-4400.

Roberts EM, Newson MJ, Pope GR, Landgraf R, Lolait SJ, and O'Carroll AM (2009)
Abnormal fluid homeostasis in apelin receptor knockout mice. $J$ Endocrinol 202: $453-462$

Roberts EM, Pope GR, Newson MJ, Landgraf R, Lolait SJ, and O'Carroll AM (2010) Stimulus-specific neuroendocrine responses to osmotic stimuli in apelin receptor knockout mice. J Neuroendocrinol 22:301-308.

Ronkainen VP, Ronkainen JJ, Hänninen SL, Leskinen H, Ruas JL, Pereira T, Poellinger L, Vuolteenaho O, and Tavi $\mathrm{P}$ (2007) Hypoxia inducible factor regulates the cardiac expression and secretion of apelin. FASEB $J$ 21:1821-1830.

Salcedo A, Garijo J, Monge L, Fernández N, Luis García-Villalón A, Sánchez Turrión V, Cuervas-Mons V, and Diéguez G (2007) Apelin effects in human splanchnic arteries. Role of nitric oxide and prostanoids. Regul Pept 144:50-55.

Sarzani R, Forleo C, Pietrucci F, Capestro A, Soura E, Guida P, Sorrentino S, Iacoviello M, Romito R, Dessì-Fulgheri P, et al. (2007) The 212A variant of the APJ receptor gene for the endogenous inotrope apelin is associated with slower heart failure progression in idiopathic dilated cardiomyopathy. $J$ Card Fail 13:521-529. Scott IC, Masri B, D'Amico LA, Jin SW, Jungblut B, Wehman AM, Baier H, Audigie Y, and Stainier DY (2007) The G protein-coupled receptor Agtrl1b regulates early development of myocardial progenitors. Dev Cell 12:403-413.

Sheikh AY, Chun HJ, Glassford AJ, Kundu RK, Kutschka I, Ardigo D, Hendry SL, Wagner RA, Chen MM, Ali ZA, et al. (2008) In vivo genetic profiling and cellular localization of apelin reveals a hypoxia-sensitive, endothelial-centered pathway activated in ischemic heart failure. Am J Physiol Heart Circ Physiol 294:H88H98.

Simpkin JC, Yellon DM, Davidson SM, Lim SY, Wynne AM, and Smith CC (2007) Apelin-13 and apelin-36 exhibit direct cardioprotective activity against ischemiareperfusion injury. Basic Res Cardiol 102:518-528.

Sörhede Winzell M, Magnusson C, and Ahrén B (2005) The apj receptor is expressed in pancreatic islets and its ligand, apelin, inhibits insulin secretion in mice. Regul Pept 131:12-17.

Sorli SC, van den Berghe L, Masri B, Knibiehler B, and Audigier Y (2006) Therapeutic potential of interfering with apelin signalling. Drug Discov Today 11:1100 1106.

Sorli SC, Le Gonidec S, Knibiehler B, and Audigier Y (2007) Apelin is a potent activator of tumour neoangiogenesis. Oncogene 26:7692-7699.

Sunter D, Hewson AK, and Dickson SL (2003) Intracerebroventricular injection of apelin-13 reduces food intake in the rat. Neurosci Lett 353:1-4.

Susaki E, Wang G, Cao G, Wang HQ, Englander EW, and Greeley GH Jr (2005) Apelin cells in the rat stomach. Regul Pept 129:37-41.

Szokodi I, Tavi P, Földes G, Voutilainen-Myllylä S, Ilves M, Tokola H, Pikkarainen S, Piuhola J, Rysä J, Tóth M, et al. (2002) Apelin, the novel endogenous ligand of the orphan receptor APJ, regulates cardiac contractility. Circ Res 91:434-440.

Taheri S, Murphy K, Cohen M, Sujkovic E, Kennedy A, Dhillo W, Dakin C, Sajedi A Ghatei M, and Bloom S (2002) The effects of centrally administered apelin-13 on food intake, water intake and pituitary hormone release in rats. Biochem Biophys Res Commun 291:1208-1212.

Tang SY, Xie H, Yuan LQ, Luo XH, Huang J, Cui RR, Zhou HD, Wu XP, and Liao EY (2007) Apelin stimulates proliferation and suppresses apoptosis of mouse osteoblastic cell line MCM-E1 via JNK and PI3-K/Akt signaling pathways. Peptides 28:708-718.

Tatemoto K, Hosoya M, Habata Y, Fujii R, Kakegawa T, Zou MX, Kawamata Y, Fukusumi S, Hinuma S, Kitada C, et al. (1998) Isolation and characterization of novel endogenous peptide ligand for the human APJ receptor. Biochem Biophys Res Commun 251:471-476.

Tatemoto K, Takayama K, Zou MX, Kumaki I, Zhang W, Kumano K, and Fujimiya M (2001) The novel peptide apelin lowers blood pressure via a nitric oxidedependent mechanism. Regul Pept 99:87-92.

Tiani C, Garcia-Pras E, Mejias M, de Gottardi A, Berzigotti A, Bosch J, and Fernandez M (2009) Apelin signaling modulates splanchnic angiogenesis and portosystemic collateral vessel formation in rats with portal hypertension. J Hepato 50:296-305

Valle A, Hoggard N, Adams AC, Roca P, and Speakman JR (2008) Chronic central administration of apelin-13 over 10 days increases food intake, body weight, locomotor activity and body temperature in C57BL/6 mice. $J$ Neuroendocrinol 20:79-84.

Van Coillie E, Proost P, Van Aelst I, Struyf S, Polfliet M, De Meester I, Harvey DJ, Van Damme J, and Opdenakker G (1998) Functional comparison of two human monocyte chemotactic protein-2 isoforms, role of the amino-terminal pyroglutamic acid and processing by CD26/dipeptidyl peptidase IV. Biochemistry 37:1267212680

Vickers C, Hales P, Kaushik V, Dick L, Gavin J, Tang J, Godbout K, Parsons T, Baronas E, Hsieh F, et al. (2002) Hydrolysis of biological peptides by human angiotensin-converting enzyme-related carboxypeptidase. J Biol Chem 277: 14838-14843

Wang G, Anini Y, Wei W, Qi X, O'Carroll AM, Mochizuki T, Wang HQ, Hellmich MR, Englander EW, and Greeley GH Jr (2004) Apelin, a new enteric peptide: localization in the gastrointestinal tract, ontogeny, and stimulation of gastric cell proliferation and of cholecystokinin secretion. Endocrinology 145:1342-1348.

Wang G, Kundu R, Han S, Qi X, Englander EW, Quertermous T, and Greeley GH Jr (2009) Ontogeny of apelin and its receptor in the rodent gastrointestinal tract. Regul Pept 158:32-39.

Wei L, Hou X, and Tatemoto K (2005) Regulation of apelin mRNA expression by insulin and glucocorticoids in mouse 3T3-L1 adipocytes. Regul Pept 132:27-32.

Xie H, Tang SY, Cui RR, Huang J, Ren XH, Yuan LQ, Lu Y, Yang M, Zhou HD, Wu $\mathrm{XP}$, et al. (2006) Apelin and its receptor are expressed in human osteoblasts. Regul Pept 134:118-125.

Xie H, Yuan LQ, Luo XH, Huang J, Cui RR, Guo LJ, Zhou HD, Wu XP, and Liao EY (2007) Apelin suppresses apoptosis of human osteoblasts. Apoptosis 12:247-254. $\mathrm{Xu}$ N, Wang H, Fan L, and Chen Q (2009) Supraspinal administration of apelin-13 induces antinociception via the opioid receptor in mice. Peptides 30:1153-1157.

Yue P, Jin H, Aillaud M, Deng AC, Azuma J, Asagami T, Kundu RK, Reaven GM, 
Quertermous T, and Tsao PS (2010) Apelin is necessary for the maintenance of insulin sensitivity. Am J Physiol Endocrinol Metab 298:E59-E67.

Zeng XX, Wilm TP, Sepich DS, and Solnica-Krezel L (2007) Apelin and its receptor control heart field formation during zebrafish gastrulation. Dev Cell 12:391-402

Zeng XJ, Zhang LK, Wang HX, Lu LQ, Ma LQ, and Tang CS (2009) Apelin protects heart against ischemia/reperfusion injury in rat. Peptides 30:1144-1152.

Zeng XJ, Yu SP, Zhang L, and Wei L (2010) Neuroprotective effect of the endogenous neural peptide apelin in cultured mouse cortical neurons. Exp Cell Res doi:10.1016/ j.yexcr.2010.02.005.

Zhang YJ, Dragic T, Cao Y, Kostrikis L, Kwon DS, Littman DR, KewalRamani VN, and Moore JP (1998) Use of coreceptors other than CCR5 by non-syncytiuminducing adult and pediatric isolates of human immunodeficiency virus type 1 is rare in vitro. $J$ Virol 72:9337-9344.

Zhang J, Ren CX, Qi YF, Lou LX, Chen L, Zhang LK, Wang X, and Tang C (2006) Exercise training promotes expression of apelin and APJ of cardiovascular tissues in spontaneously hypertensive rats. Life Sci 79:1153-1159.

Zhang R, Hu C, Wang CR, Ma XJ, Bao YQ, Xu J, Lu JY, Qin W, Xiang KS, and Jia WP (2009a) Association of apelin genetic variants with type 2 diabetes and related clinical features in Chinese Hans. Chin Med J (Engl) 122:1273-1276.
Zhang Q, Yao F, Raizada MK, O'Rourke ST, and Sun C (2009b) Apelin gene transfer into the rostral ventrolateral medulla induces chronic blood pressure elevation in normotensive rats. Circ Res 104:1421-1428.

Zhang Z, Yu B, and GZ (2009c) Apelin protects against cardiomyocyte apoptosis induced by glucose deprivation. Chin Med J (Engl) 122:2360-2365.

Zhao Q, Hixson JE, Rao DC, Gu D, Jaquish CE, Rice T, Shimmin LC, Chen J, Cao J, Kelly TN, et al. (2010) Genetic variants in the apelin system and blood pressure responses to dietary sodium interventions: a family-based association study. $J H y$ pertens 28:756-763.

Zhong JC, Huang DY, Liu GF, Jin HY, Yang YM, Li YF, Song XH, and Du K (2005) Effects of all-trans retinoic acid on orphan receptor APJ signaling in spontaneously hypertensive rats. Cardiovasc Res 65:743-750.

Zhou N, Fang J, Acheampong E, Mukhtar M, and Pomerantz RJ (2003) Binding of ALX40-4C to APJ, a CNS-based receptor, inhibits its utilization as a co-receptor by HIV-1. Virology 312:196-203.

Zou MX, Liu HY, Haraguchi Y, Soda Y, Tatemoto K, and Hoshino H (2000) Apelin peptides block the entry of human immunodeficiency virus (HIV). FEBS Lett 473:15-18 